\title{
Urea and ammonia metabolism in the human large intestine
}

\author{
By Oliver M. Wrong and Angela Vince, Department of Medicine, The Rayne \\ Institute, University College, London $W C_{\mathrm{I}} E 6 \mathfrak{F}$
}

Man passes each day 100-200 $\mathrm{g}$ faeces containing $\mathrm{I}-2 \mathrm{~g}$ bound nitrogen. The chemical nature of this $\mathbf{N}$ is not completely clear, although recent studies suggest that it lies predominantly in faecal bacteria, which collectively make up 40-70\% of faecal wet weight (Stephen \& Cummings, 1980). The work we shall present here is concerned with the analysis of this faecal $\mathrm{N}$, and here one immediately comes up against a technical problem: how does one analyse labile nitrogenous substances such as urea and ammonia in an offensive, variably-coloured material which has the consistency of a solid despite being $75 \%$ water, and is, moreover, the site of intense bacterial activity? Over 20 years ago the technique of in vivo faecal dialysis (Wrong et al. 1961, 1965) was developed to deal with this problem. The experimental subject swallows small dialysis capsules made of cellulose tubing, and 24-120 h later these are recovered when passed in the stool. Except in diarrhoeal states the capsules spend at least $20 \mathrm{~h}$ in the large intestine which is ample time to achieve diffusion equilibrium with large bowel contents. The fluid contained in the capsules is a dialysate of distal faeces and can be analysed by conventional techniques. The method samples only the extracellular component of stool water and not the water enclosed in the cell membranes of bacteria and epithelial cells. Other workers have obtained faecal water by fractionation of faeces outside the body, using high-speed centrifugation (Tarlow \& Thom, r974) or ultrafiltration (Bjork et al. 1976). These methods produce fluids of similar composition to in vivo dialysate with respect to inorganic electrolytes, but of higher ammonia and organic acid concentrations and lower $\mathrm{pH}$ and bicarbonate concentration (Table $\mathrm{I}$ ). Our own studies, some of which we describe here, show that these differences arise

Table I. Mean values for concentrations of solutes ( $\mathrm{mmol} / \mathrm{l})$ in faecal water from human subjects, obtained by various techniques

$\begin{array}{lccc} & \begin{array}{c}\text { In vivo } \\ \text { faecal dialysis }\end{array} & \begin{array}{c}\text { High-speed } \\ \text { faecal } \\ \text { centrifugation }\end{array} & \begin{array}{c}\text { Faecal } \\ \text { ultrafiltration }\end{array} \\ \text { Osmolality (mosm/kg) } & 376 & 475 & 410 \\ \text { pH } & 7 \cdot 0 & 6 \cdot 1 & - \\ \text { Sodium } & 32 & 32 & 24 \\ \text { Potassium } & 75 & 70 & 83 \\ \text { Ammonia } & 14 & 33 & 42 \\ \text { Chloride } & 16 & 23 & 11 \\ \text { Total carbon dioxide } & 40 & 7 \cdot 3 & 18 \\ \text { Organic anion } & 172 & 203 & 196\end{array}$


from handling of faeces outside the body, which allows continuing bacterial generation of organic acids and ammonia. For the purpose of the present paper these differences are not important, but are mentioned to indicate some of the technical problems involved.

\section{Quantitative aspects}

Faecal dialysate contained $90 \mathrm{mmol}$ bound N/l which represents only $9 \%$ of the total faecal $\mathrm{N}$. The $91 \%$ of faecal $\mathrm{N}$ which is not diffusible is probably bound in bacteria, largely as bacterial protein, though some of it may represent smallmolecular-size intracellular $\mathrm{N}$ compounds such as amino acids and ammonia. Of the $90 \mathrm{mmol}$ diffusible $\mathrm{N} / \mathrm{l}, \mathrm{I}_{5} \mathrm{mmol} / \mathrm{l}$ or one-sixth is ammonia. The identity of the remainder is not clear, but it does not consist of urea, free amino acids, or volatile amines such as dimethylamine which give the Conway reaction (Wrong et al. 1965; Owens \& Padovan, 1976). It may consist partly of higher amines produced by bacterial decarboxylation of amino acids, such as putrescine and cadaverine, and the breakdown products of various small-molecular-weight nitrogenous compounds, such as purines and creatinine, which are known to be destroyed by intestinal bacteria (Wrong et al. 1981).

\section{Importance of intestinal ammonia}

The ammonia in faecal dialysate represents only $\mathrm{I}-2 \%$ of total faecal $\mathrm{N}$, yet at an average level of $14 \mathrm{mmol} / \mathrm{l}$ it is present at a higher concentration than in any other body fluid except urine. The renal physician at one time found faecal ammonia of interest because it was widely believed to be derived from bacterial hydrolysis of endogenous urea, and increased production when the blood urea concentration was raised by renal failure was regarded as the cause of 'uraemic' colitis (Williams \& Dick, r933), a concept which finds little credence among contemporary nephrologists who recognize several other reasons for colitis in patients with renal failure. The liver expert is interested in intestinal ammonia because it is absorbed into the portal vein whence it is normally recycled into urea in the liver, but in liver disease it may reach the systemic circulation where it is believed to play a role in the neuropsychiatric features of porto-systemic encephalopathy or 'liver coma' (Conn \& Lieberthal, 1979). Intestinal ammonia is also of clinical interest as a possible aetiological agent in cancer of the large bowel (Visek, 1972), at present responsible for approximately ro 000 deaths annually in the UK.

However, ammonia is of greater biological interest as the simplest nitrogenous substance that can be used by living organisms for protein synthesis. Studies of protein-deprived humans have showed that their $\mathrm{N}$ needs, except for essential amino acids, can be met by ammonia, and that even the so-called 'essential' amino acids are not truly essential (apart from lysine and threonine) but can be synthesized from ammonia in the body provided their carbon skeletons are available as the appropriate keto- or hydroxy-acids (Jackson, 1983). Bacteria are even more versatile: all can utilize ammonia for their $\mathrm{N}$ requirements, many can 
use it as their only $\mathrm{N}$ source and some make use of it in preference to other $\mathrm{N}$ sources such as amino acids (Hobson \& Summers, 1967; Dawes \& Large, 1973). Bacteria, including those in the intestine, are also active producers of ammonia from many sources, including deamination of amino acid-N and hydrolysis of urea. The key position of intestinal ammonia in the protein anabolism and catabolism of both intestinal bacteria and their human host is to us of greater interest than its still largely theoretical role in human disease.

\section{Sources of intestinal ammonia}

The main sources and fates of intestinal ammonia are shown in Fig. I. All the steps illustrated have been well demonstrated, but there are still doubts about the relative contributions of the various pathways and the exact site in the intestine where the different events occur.

The main source of intestinal ammonia was long regarded as endogenous urea (Sabbaj et al. 1970; Summerskill \& Wolpert, 1970), largely because of the enormous amounts of urea known to be degraded in the body. Urea degradation has been demonstrated by various techniques, including loss of ${ }^{14} \mathrm{C}$ as respiratory carbon dioxide after intravenous administration of $\left[{ }^{14} \mathrm{C}\right]$ urea and the appearance of isotopic $\mathrm{N}$ in tissue proteins after administration of $\left[{ }^{15} \mathrm{~N}\right]$ urea. Quantitative estimates have been obtained by labelling of plasma urea with ${ }^{14} \mathrm{C}$ or ${ }^{13} \mathrm{C}$, and subsequent comparison of calculated rates of urea synthesis with observed rates of urea excretion. Estimated in this way, urea degradation in healthy man has averaged $21 \%$ of the synthesis, or $56 \%$ of the urea pool each day, equivalent to about $7 \mathrm{~g}$ urea daily. These values are lower than those found in animals with complex fermentation chambers in fore-gut or hind-gut (Table 2) but of the same order of magnitude. Pregnancy and protein starvation increase urea degradation

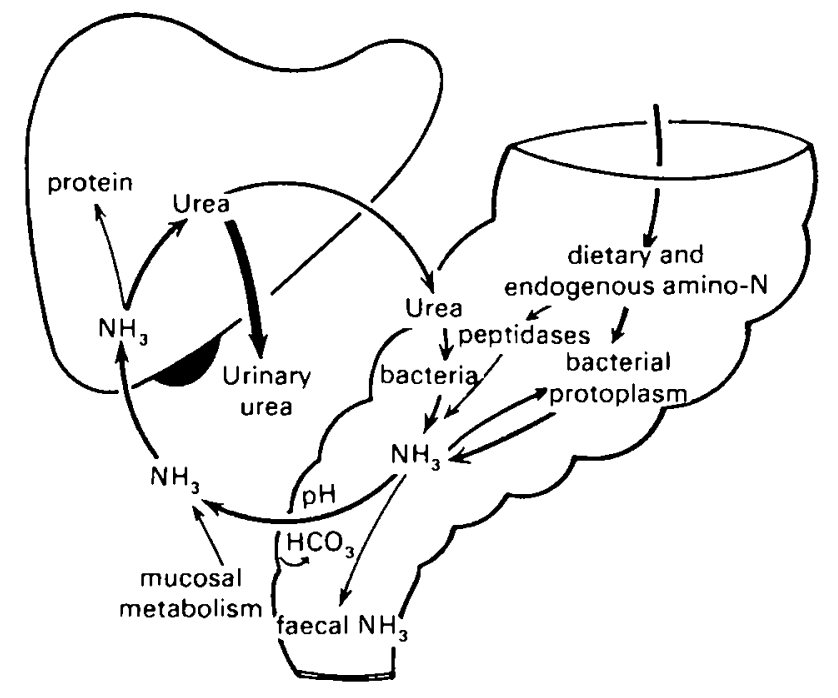

Fig. I. The origins and fates of intestinal ammonia. 
Table 2. Rates of urea degradation in different mammals (mean values) from Wrong et al. (198I)

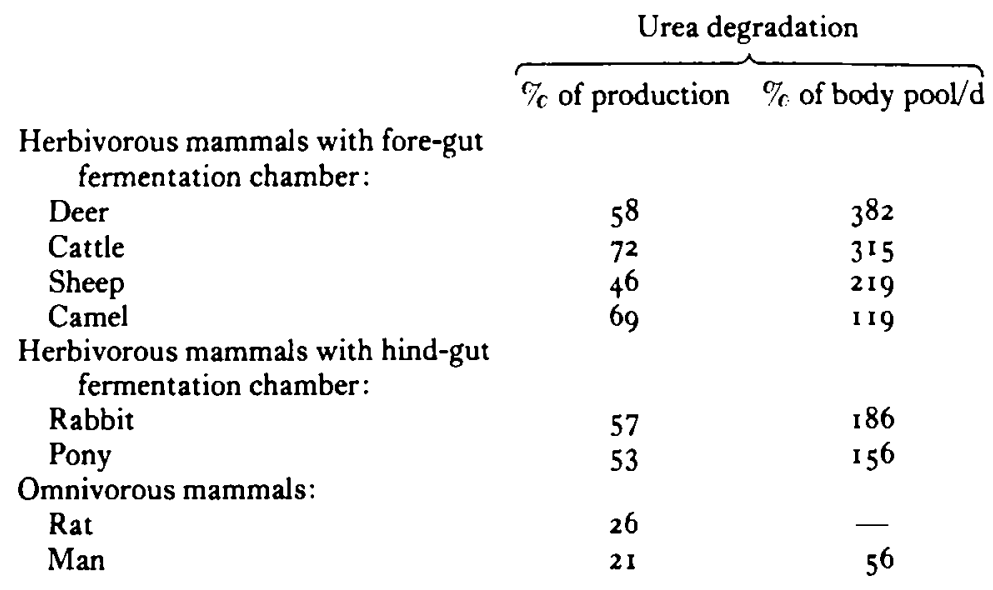

rates as a proportion of urea production, and in so doing probably increase recycling of urea- $\mathrm{N}$ into tissue protein, which is desirable under these circumstances (Jackson, 1983).

The evidence that endogenous urea degradation is caused by the activity of urease-producing bacteria in the alimentary tract is fairly convincing. Ammonia concentrations in portal venous blood are much higher than in peripheral blood (Conn \& Lieberthal, 1979) and in man correspond, when calculations are made from portal blood flow, to known rates of urea degradation in the whole body (Wolpert et al. 1971). In experimental animals blood ammonia concentrations are highest in the vein draining the colon (Folin \& Denis, r912). In animals and man, urea destruction is reduced by the feeding of unabsorbed antibiotics (Dintzis \& Hastings, 1953; Walser \& Bodenlos, 1959; Jones et al. 1969; McKinley et al. 1970) and in the rat is virtually abolished by evisceration or rearing in germ-free conditions (Chao \& Tarver, 1953; Levenson et al. 1959). The large intestine contains an abundance of urea-splitting organisms, particularly non-sporing anaerobes (Vince et al. 1973); these bacteria can also be cultured from the small intestine, particularly the terminal ileum, but their numbers there are several log units less than in the large intestine which is therefore regarded as the main site of intestinal urea hydrolysis.

Bacterial degradation of urea involves production of ammonia as the first step. The absence of urea and the presence of ammonia in normal faecal dialysate are further pieces of evidence supporting urea as the major source of intestinal ammonia. Urea appears in faecal dialysate at close to blood concentrations when subjects are given unabsorbable antibiotics, and ammonia concentrations fall but not to zero (Wilson et al. 1968a). Uraemic subjects have higher faecal ammonia levels than normal subjects, and occasional traces of urea spontaneously appear in 
their faeces though always at much lower concentrations than in blood unless subjects are taking antibiotics (Wilson et al. 1968b).

Against these arguments in favour of endogenous urea as a major source of intestinal ammonia is the observation by two groups of workers that the human large intestine is almost impermeable to urea (Wolpert et al. 1971; Bown et al. 1975). This finding is not as convincing evidence against the role of urea as might at first appear, for the studies were performed on organs which were cleansed of their normal contents. Mucosal permeability to various substances, including urea, is markedly reduced in the absence of bile salts and hydroxy-fatty acid anions (Dobbins \& Binder, 1976; Gaginella et al. 1977), normal bowel constituents, which were certainly lacking in these experiments, and the impermeability of the mucosa to urea might therefore have been largely an artefact of these experimental conditions. Those who nevertheless accept that the large bowel mucosa is impermeable to urea have the problem of defining the site of urea degradation; this they do by postulating that urea degradation does not occur in the large bowel lumen, but either within the mucosa of the bowel, or in the terminal ileum which has a mucosa known to be relatively permeable to urea.

At this point we became involved in an observation which pointed to the existence of sources of faecal ammonia other than urea. As already indicated, faeces generate large amounts of ammonia in vitro, although they contain no urea, an observation first made by Gamble (1915) and quoted by early biochemists as a reason for storing stools required for $\mathrm{N}$ analysis in strong acid to prevent ammonia loss by volatilization. We took this matter further and found that faeces incubated anaerobically, with excellent survival of their bacterial flora, converted some $12 \%$ of their total $\mathrm{N}$ to ammonia, and even more when bacterial survival was impaired (Fig. 2). Total sterilization of faeces by $\gamma$-irradiation did not prevent this generation of ammonia, though sterilization by autoclaving did so, and hence we infer that this ammonia generation depends on the existence of bacterial enzymes rather than of living bacterial bodies (Vince et al. 1976). The amount of ammonia liberated is so large that we conclude it must be derived from bacterial proteins, by hydrolysis and deamination.

By 1980 the arguments for and against endogenous urea as the main source of intestinal ammonia were so contradictory that we determined to seek an answer by direct experiment, at least as far as faecal ammonia was concerned (Wrong et al. 1982). Two healthy subjects were given a constant three-hourly diet to ensure relatively constant endogenous production of urea, and were infused intravenously at a constant rate with ${ }^{15} \mathrm{~N}$-labelled urea as tracer. By these means we were able to maintain a constant ${ }^{15} \mathrm{~N}$ enrichment of plasma urea for over $3 \mathrm{~d}$, a period longer than that of a complete gastrointestinal transit. The ${ }^{15} \mathrm{~N}$ enrichment of faecal ammonia could then be compared with that of the plasma urea- $\mathrm{N}$ which was circulating when the faeces were formed in the body. The results of the two experiments were identical; faecal ammonia- $N$, whether obtained by in vivo faecal dialysis, centrifugation of faeces or ultrafiltration of faecal incubate outside the body, had a ${ }^{15} \mathrm{~N}$ enrichment which was only $8.5 \%$ of the corresponding plasma 


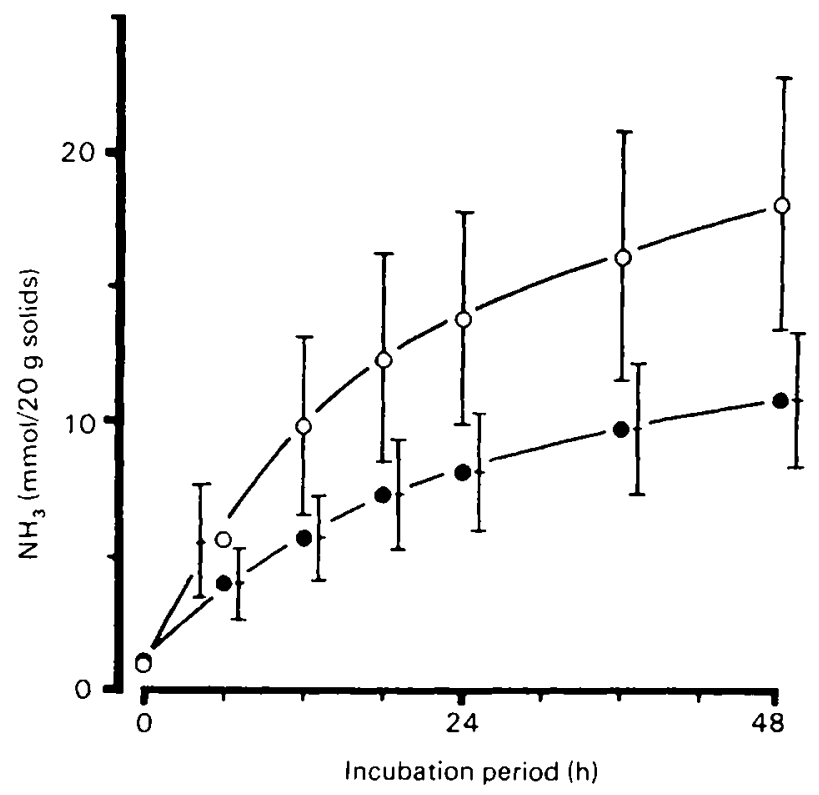

Fig. 2. Generation of ammonia in an anaerobic faecal incubation system. $\mathrm{NH}_{3}$ values are expressed per $20 \mathrm{~g}$ faecal solids, as this represents an average $24 \mathrm{~h}$ production of faeces. ( $(\mathbf{)})$, Mean values from a $\mathrm{I}: 4$ dilution of faeces in saline ( $9 \mathrm{~g}$ sodium chloride/l), in which bacterial numbers did not change significantly during $48 \mathrm{~h}$ of incubation; $(O)$, mean values from a $1: 3$ dilution in saline, in which bacterial numbers declined during incubation; from Vince et al. (1976).

urea value. The enrichment of faecal total $\mathrm{N}$ was only slightly (but significantly) less at $6.8 \%$ of the plasma urea value. Thus in these two studies an average of over $90 \%$ of faecal ammonia- $\mathrm{N}$ must have been derived from non-urea sources, of which the major one was likely to be the protein of intestinal bacteria. The very similar enrichment of faecal total $\mathrm{N}$ suggests that it was in close chemical exchange with faecal ammonia, in keeping with other observations reported here (Figs. 2 and 3 ).

The minor contribution of endogenous urea to faecal ammonia shown by these experiments surprised us. It suggests that the bacterial hydrolysis of the large amount of urea known to be degraded in the body does not contribute much to the ammonia in the lumen of the large bowel, perhaps because the suggestion that hydrolysis occurs at a 'juxtamucosal' site (Wolpert et al. 1971) is fundamentally correct, the ammonia liberated being absorbed into the blood stream and relatively little passing into the bowel lumen. It would be interesting to see the result of a similar ${ }^{15} \mathrm{~N}$ study on portal venous ammonia, as we suspect that a much larger proportion of this would be derived from endogenous urea, but we know of no such study in man. However, Weber \& Veach (1979) have investigated the origins of portal venous ammonia in the dog, and found that half this comes from the small intestine from metabolism of glutamine, $2 \mathrm{r} \%$ is derived from breakdown of urea in the large intestine and $5 \%$ is derived from mucosal metabolism of glutamine in the 
large intestine. This study, although on another species, confirms that endogenous urea can contribute proportionately more to portal ammonia than it does to faecal ammonia, and measures a non-bacterial mucosal source of portal ammonia which had earlier been demonstrated by studies of Windmueller \& Spaeth (1974) on small bowel mucosa.

\section{Utilization of ammonia by intestinal bacteria}

Our faecal incubation system generates net ammonia, bacterial utilization of ammonia being masked by bacterial production of ammonia. Within the large bowel lumen, $\mathbf{N}$ is reduced during transit from ileocaecal valve to anus (Gibson et al. 1976) which suggests continued generation of ammonia which leaves the intestine by mucosal absorption. However, net ammonia utilization by intestinal bacteria becomes apparent when fermentable substrates, such as glucose, lactulose or mannitol, are added to our faecal incubation system (Vince et al. 1978); the ambient ammonia concentration, which would otherwise rise steeply during incubation, diminishes or disappears altogether (Fig. 3). Bacterial generation of organic acid from these substrates lowers the $\mathrm{pH}$ of the homogenate and this itself reduces bacterial metabolism and so impairs ammonia production, so the effect of these bacterial substrates on ammonia utilization is best seen when the sample is titrated to prevent the $\mathrm{pH}$ falling below 5.5 . We find a similar change in ammonia generation in our faecal incubation system when various preparations of plant fibre

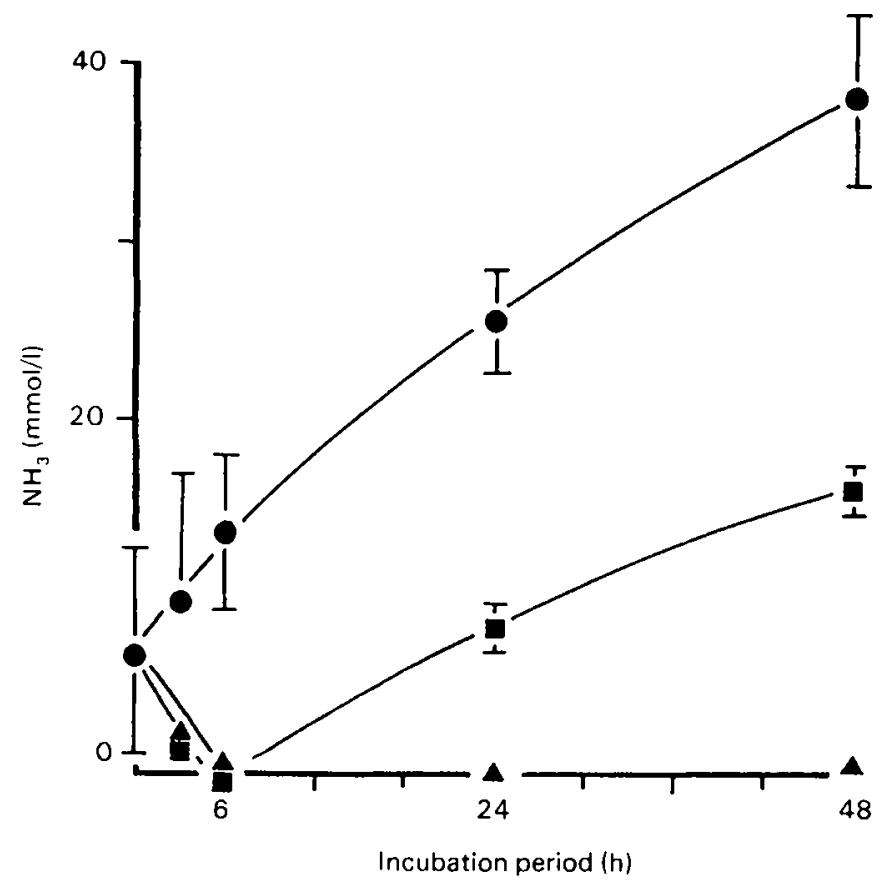

Fig. 3. The effect of $0.09 \mathrm{~mol}$ lactulose/ 1 in an anaerobic faecal incubation system ( $1: 4$ dilution of faeces in saline). For explanation, see above. From Vince et al. (1978) by permission of

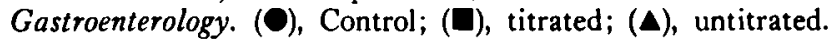


are added, particularly so with pectin and to a lesser extent with the hemicellulose arabinogalactan (O. M. Wrong and co-workers, unpublished results). Fermentation of these carbohydrates is slower than that of lactulose or glucose, as shown by a lower rate of production of organic acid; net ammonia generation shows a decline rather than a reversal to net ammonia uptake as in the case of lactulose.

These observations provide one explanation for the effect of plant fibre, and of non-fibrous carbohydrates such as lactulose which escape digestion in the small intestine, in increasing faecal $\mathrm{N}$ loss in both man and domestic animals (Sealock et al. I941; Mason \& Palmer, 1973; Weber, 1979; Stephen \& Cummings, 1979). This effect has long been recognized, and usually attributed to interference with protein digestion, caused by fibre bulk or intestinal hurry, but it is clear that a more subtle influence on bacterial metabolism is also involved. In herbivorous animals subsisting on a high-roughage low-protein intake the resultant obligatory loss of bacterial $\mathrm{N}$ in the faeces may be important, representing more than $50 \%$ of total $\mathrm{N}$ intake (Thornton et al. $\mathrm{I} 970$ ). The role of this factor in human nutrition is still unknown; calculation suggests that it may be important, as an increase in faecal $\mathrm{N}$ of $\mathrm{I} \mathrm{g} / \mathrm{d}$ (a reasonable increment to result from increased fibre intake) represents a loss of body $\mathrm{N}$ equivalent to over $6 \mathrm{~g}$ protein/d, a significant amount for a protein-deprived man.

\section{Ammonia absorption from the large intestine}

Although the ammonia concentration of faeces is high in relation to other body fluids, the amount passed in stools each day is small in relation both to the urea degradation rate and the amount of ammonia generated by faeces during incubation. Clearly, therefore, large amounts must be absorbed through the intestinal mucosa. There is no evidence that absorption is active, but it is greatly enhanced from a more alkaline medium (Castell \& Moore, 1971; Down et al. 1972), suggesting that the main mechanism is by passive non-ionic diffusion. Bacterial activity in the large intestine tends constantly to generate organic acids, which render the lumen more acid, but this tendency is counteracted by active mucosal secretion of bicarbonate which produces an alkaline reaction favourable to ammonia absorption (Wrong et al. $198 \mathrm{r}$ ).

The ammonia absorbed from the intestine, and that produced by mucosal metabolism, enters the portal vein and is transported to the liver as the highly-water-soluble ammonium ion $(\mathrm{p} K \mathrm{q} \cdot \mathrm{I})$. Theoretically ammonia might also be transported by intestinal lymphatics into the systemic circulation, but the rapid rate of portal venous flow and the contrast between the ammonia content of portal and systemic blood make clear that the portal vein is the main avenue of transport.

Within the liver most of the portal ammonia enters the Krebs-Henseleit cycle and is converted to urea, although a moiety is transaminated to amino acids. The factors controlling the Henseleit pathway are poorly understood and the full potential of this route for human nutrition is still not known (Jackson, 1983 ). This subject is likely to be the scene of exciting and rapid advance in the next few years.

The Medical Research Council supported this work. 


\section{REFERENCES}

Bjork, J. T., Soergel, K. H. \& Wood, C. M. (1976). Gastroenterology 70, 864.

Bown, R. L., Gibson, J. A., Fenton, J. C. B., Snedden, W., Clark, M. L. \& Sladen, G. E. (1975). Clinical Science and Molecular Medicine 48, 279-287.

Castell, D. O. \& Moore, E. W. (1971). Gastroenterology 60, 33-42.

Chao, F. C. \& Tarver, H. (1953). Proceedings of the Society for Experimental and Biological Medicine 84, 406-409.

Conn, H. O. \& Lieberthal, M. M. (1979). The Hepatic Coma Syndromes and Lactulose. Baltimore: Williams and Wilkins.

Dawes, E. A. \& Large, P. J. (1973). In Biochemistry of Bacterial Growth, pp. 202-256 [J. Mandelstam and K. McQuillen, editors]. Oxford: Blackwell Scientific Publications.

Dintzis, R. Z. \& Hastings, A. B. (1953). Proceedings of the National Academy of Sciences, USA 39, $571-578$.

Dobbins, J. W. \& Binder, H. J. (1976). Gastroenterology 70, 1096-1 100.

Down, P. F., Agostini, L., Murison, J. \& Wrong, O. M. (1972). Clinical Science 43, 101-114.

Folin, O. \& Denis, W. (1912). Fournal of Biological Chemistry 11, 161-167.

Gaginella, T. S., Chadwick, V. S., Debognie, J. C., Lewis, J. C. \& Phillips, S. F. (1977). Gastroenterology 73, 95-101.

Gamble, J. L. (1915). American Journal of Diseases of Children 9, 519-532.

Gibson, J. A., Sladen, G. E. \& Dawson, A. M. (1976). British fournal of Nutrition 35, 6r-65.

Hobson, P. N. \& Summers, R. (1967). Fournal of General Microbiology 47, 53-65.

Jackson, A. A. (1983). Lancet i, 1034-1037.

Jones, E. A., Smallwood, R. A., Craigie, A. \& Rosenoer, V. M. (1969). Clinical Science $37,825-83^{6}$.

Levenson, S. M., Crowley, L. V., Horowitz, R. E. \& Malm, O. J. (1959). Fournal of Biological Chemistry 234, 2061-2062.

McKinley, J. E., Gilbert, D. B., Chao, P. Y. \& Reeve, E. B. (1970). American fournal of Physiology 218, 49 I -497 .

Mason, V. C. \& Palmer, R. M. (1973). Proceedings of the Nutrition Society 32, 82A, 83A.

Owens, C. W. I. \& Padovan, W. (1976). Gut 1 7, 68-74.

Sabbaj, J., Sutter, V. L. \& Finegold, S. M. (1970). Antimicrobial Agents and Chemotherapy, $181-185$.

Sealock, R. R., Basinski, D. H. \& Murlin, J. R. (1941). Journal of Nutrition 22, 589-596.

Stephen, A. M. \& Cummings, J. H. (1979). Proceedings of the Nutrition Society 38, 14 IA.

Stephen, A. M. \& Cummings, J. H. (1980). Journal of Medical Microbiology 13, 45-56.

Summerskill, W. H. J. \& Wolpert, E. (1970). American fournal of Clinical Nutrition 23, 633-639.

Tarlow, M. J. \& Thom, H. (1974). Gut 15, 608-613.

Thornton, R. F., Bird, P. R., Somers, M. \& Moir, R. J. (1970). Australian fournal of Agricultural Research 21, 345-354.

Vince, A., Dawson, A. M., Park, N. \& O'Grady, F. (1973). Gut 14, 171-1 77.

Vince, A., Down, P. F., Murison, J., Twigg, F. J. \& Wrong, O. M. (1976). Clinical Science and Molecular Medicine 51, 313--322.

Vince, A., Killingley, M. \& Wrong, O. M. (1978). Gastroenterology 74, 544-549.

Visek, W. J. (1 972). Federation Proceedings 31, I $178-1193$.

Walser, M. \& Bodenlos, L. J. (1959). Fournal of Clinical Investigations 38, $1617-1626$.

Weber, F. L. (1979). Gastroenterology 77, 518-523.

Weber, F. L. \& Veach, G. H. (1979). Gastroenterology 77, 235-240.

Williams, J. L. \& Dick, G. F. (1933). Fournal of the American Medical Association 100, 484-487.

Wilson, D. R., Ing, T. S., Metcalfe-Gibson, A. \& Wrong, O. M. (1968a). Clinical Science 34, $21 I-22 I$.

Wilson, D. R., Ing, T. S., Metcalfe-Gibson, A. \& Wrong, O. M. (1968b). Clinical Science 35, 197-209.

Windmueller, H. G. \& Spaeth, A. E. (1974). Fournal of Biological Chemistry 249, 5070-5079.

Wolpert, E., Phillips, S. F. \& Summerskill, W. H. J. (1971). Lancet ii, 1387-1 390. 
Wrong, O. M., Edmonds, C. J. \& Chadwick, V. S. (1981). The Large Intestine. Lancaster: MTP Press.

Wrong, O. M., Metcalfe-Gibson, A., Morrison, R. B. I., Ng, S. T. \& Howard, A. V. (1965). Clinical Science 28, 357-375.

Wrong, O. M., Morrison, R. B. I. \& Hurst, P. E. (1961). Lancet i, 1208-1 209.

Wrong, O. M., Vince, A. J. \& Waterlow, J. C. (1982). In Colon and Nutrition, pp. 133-137

[H. Kasper and H. Goebell, editors]. Lancaster: MTP Press. 